\title{
Determinants of Economic Growth in Turkey in the Presence of Structural Breaks
}

Natalya KETENCİ (https://orcid.org/0000-0002-7299-2833), Department of Economics, Yeditepe University, Turkey; e-mail: nketenci@yeditepe.edu.tr

Ebru Tomris AYDOĞAN (https://orcid.org/0000-0002-1529-5484), Department of Economics, Yeditepe

University, Turkey; e-mail: taydogan@yeditepe.edu.tr

\section{Yapısal Kırılmaların Varlığında Türkiye'de Ekonomik Büyümenin Belirleyicileri}

\begin{abstract}
Sustainable economic growth is defined as a continuous increase in environmentally adjusted net domestic product (Bartelmus, 1994). This study investigates the role of natural gas consumption and trade openness in relation with the economic growth of Turkey for the period 1977-2017 throughout which Turkey underwent several political and economic shocks. To accomplish this, the paper employs the Kejriwal and Perron (2010) structural break test to investigate the relationship between economic growth and its determinants in the presence of structural shifts. By demonstrating the impacts of variables on economic growth through different sub-regimes, the outcomes underline the importance of structural breaks in estimations.

Keywords

: Economic Growth, Natural Gas Consumption, Energy Use, Cointegration, Structural Breaks, Turkey.

JEL Classification Codes : $\quad$ O11, O13, F41.

Öz

Sürdürülebilir ekonomik büyüme, çevresel olarak düzeltilmiş net yerli hasılada sürekli bir artıştır (Bartelmus, 1994). Bu çalışma, 1977-2017 dönemi için doğal gaz tüketiminin ve dışa açıklığın Türkiye'nin ekonomik büyümesindeki rolünü incelemektedir. Türkiye bu dönemde çeşitli siyasi ve ekonomik şoklar geçirdi. Bu nedenle, makale ekonomik büyüme ve belirleyicileri arasındaki ilişkiyi yapısal kırılmaların varlığında araştırmak için Kejriwal ve Perron (2010) yapısal kırılma testini kullanmaktadır. Sonuçlar, değişkenlerin ekonomik büyüme üzerindeki etkilerini alt rejimler yoluyla ayrıntılı bir şekilde göstererek, tahminlerde kırılmanın önemini vurgulamaktadır.
\end{abstract}

Anahtar Sözcükler $\quad$ : Ekonomik Büyüme, Doğal Gaz Tüketimi, Enerji Kullanımı, Eştümleşme, Yapısal Kırılmalar, Türkiye. 


\section{Introduction}

Sustainable economic growth became a matter of discussion in the 1970s when the world economies witnessed major oil crises in 1973 and 1979. During the 1980s, international competition, investments, and trade openness increased with globalization. Like many other developing countries, Turkey also struggled with several crises throughout the last three decades. Both developed and developing economies aim to achieve sustainable economic growth without destroying or damaging the rights of their future generations. Therefore, shedding some light on the sustainability of environmental resources as well as decreasing environmental destruction and degradation is the key for the achievement of sustainable development in the long run.

Energy is an important determinant of economic growth especially in emerging countries. The increase in production leads to both an increase in energy consumption and the rate of economic growth (Cheng \& Lai, 1997). Economic growth may be maintained with the implementation of policies that support the use of more efficient and eco-friendly energy sources that create less pollution (Belke et al., 2010).

Natural gas is one of the most important sources of energy because it is used not only for consumption, but for the production of other energy sources as well. Thus, in 2011, $20 \%$ and $21 \%$ of natural gas in Turkey was consumed by the residential and industrial sectors, respectively, while $48 \%$ of total natural gas consumption was used in the electric power sector. During the previous decade, natural gas consumption soared in Turkey. From 2000 to 2009 , the consumption of natural gas by the power generation sector increased from 795 million cubic feet per day to 1.9 billion cubic feet. The residential sector increased its natural gas consumption from 289 to 516 million cubic feet for the same period, while the highest increase took place in the commercial sector, which increased its consumption from 45 to 243 million cubic feet. ${ }^{1}$

For several decades the dependence of Turkey on trade increased significantly as well. In 1997, the exports and imports of Turkey composed 3.82\% and $10.71 \%$ of the GDP, in turn. In 2014, these numbers increased to $27.72 \%$ and $32.13 \%$, respectively. Therefore, the trade openness of Turkey increased for this period, from $14.52 \%$ to $59.85 \%$, indicating that trade openness is an important part of the Turkish output. ${ }^{2}$ For this reason, natural gas, together with investments, labor, and trade openness are the main determinants of economic growth in this study.

This study analyzes the relationship between aggregate output, natural gas, investments, labor, and trade openness in Turkey when structural breaks are allowed for the period from 1977 to 2017. Sustainable economic growth of a country is an indicator of a

1 Source: International Energy Agency.

2 Source: World Development Indicators. 
strong economic system, which is able to cooperate and compete at an international level. However, the impact of the considered determinants on the economic growth of Turkey may not be straightforward as the economy has passed through continuous domestic changes and been affected by external changes that took place in the partner countries.

Since 1977, Turkey has witnessed several domestic and international crises that could change the relationship between aggregate output and its proposed determinants. Turkey experienced an economic crisis between the 1977-79 period mainly due to the OPEC oil crisis and her debt and balance of payments problems. The structural adjustment program of January 1980 suggested the implementation of export promotion strategy and trade liberalization (1980-1984) for the economic growth of Turkey (Boratav \& Yeldan, 2006). Financial liberalization (1985-89) aimed to restore stability and growth in order to increase the efficiency and saving in the economy. After the economic crisis of 1982 and with the application of the program, the Turkish economic growth accelerated due to the rising export levels and declining inflation rate. The enactment of Decree 32 in 1989 allowed for capital mobility after the convertibility of the Capital Account was put into force. Short-term capital in and outflows increased the fragility of the Turkish economy and left her vulnerable to economic crises (Aydoğan, 2010). Political instability and semi-autonomous Central Bank have triggered the problem of high inflation starting as of 1970s till 2004. The public sector borrowing requirement and public debt stock rose with the increase in the balance of payments deficit (Ar1 \& Cergibozan, 2014). Although the real domestic interest rates peeked; investments and economic growth came to a halt. International Monetary Fund (IMF) announced a stand-by agreement for Turkey in April 1994 (Ertuğrul \& Selçuk, 2001). The 1997-98 Asian and the 1998 Russian crises hit the Turkish economy severely. In January 2000 the IMF Disinflation Program was launched for economic stability. In February 2001, the political dispute between the Prime Minister and the President of Turkey finalized the program earlier than its expected deadline. Finally, the 2008-09 crisis led to an economic downturn thereby fostering higher unemployment rates and lower export revenues and thus economic recession in the Turkish economy (Ar1 \& Cergibozan, 2014). The 1990s and 2000s set the stage for many other economic crises that occurred in the Turkish economy respectively in: 1994, 1998-99, 2000-01, and 2008-09. Therefore, when analyzing the determinants of economic growth, it is important to take the structural breaks that may take place during the estimated period into account.

The contribution of this study to the literature is the integration of structural breaks in the analysis of economic growth. To our knowledge, structural breaks were not applied in this context in the literature. This study employs econometric approaches such as the Perron-Yabu (2009) and the Kejriwal and Perron (2010) tests that detect the presence of possible structural shifts in series, as well as cointegrating relationships. It also compares the results of traditional tests such as the Dynamic Ordinary Least Squares (DOLS) and Fully Modified Ordinary Least Squares (FMOLS) with the results that are acquired when the structural shifts are accounted for. The rest of the paper is organized as follows. Section 2 presents the review of empirical studies on the determinants of economic growth, particularly consumption of different sources of energy. In section 3 , the economic growth 
Ketenci, N. \& E.T. Aydoğan (2019), "Determinants of Economic Growth in

Turkey in the Presence of Structural Breaks", Sosyoekonomi, Vol. 27(42), 11-28.

model and estimation methodology are demonstrated. Section 4 presents the empirical results, and the final section concludes.

\section{Literature Review}

The relationship between economic growth and energy consumption is studied in the literature under four hypotheses: growth, conservation, feedback, and neutrality (Apergis \& Payne, 2009; Abbasian et al., 2010). According to the growth hypothesis, energy consumption affects economic growth considerably; the causal relationship is from energy consumption to economic growth (Yu \& Choi, 1985; Masih \& Masih, 1997; Thoma, 2004, Farhani et al., 2014). Thus, policies and regulations that decrease the energy usage of a country may reduce economic growth or bring it to a halt.

The conservation hypothesis suggests that the causal relationship is unidirectional from economic growth to energy consumption (Kraft \& Kraft, 1978; Cheng \& Lai, 1997; Aqeel \& Butt, 2001; Hatemi \& Irandoust, 2005; Yong-Xiu et al., 2007; Zamani, 2007; Zhang \& Cheng, 2009; Binh, 2011; Souhila \& Kourbali, 2012). Paul and Bhattacharya (2004) state that energy conservation policies may not influence economic growth negatively; rather, they may not influence it at all.

The feedback hypothesis proposes that a bidirectional causal relationship exists between energy consumption and economic growth (Hwang \& Gum, 1991; Hondroyiannis et al., 2002; Paul \& Bhattacharya, 2004; Hou, 2009). Sebri and Salha (2014) analyze the long-run and causal relationships between economic growth, renewable energy consumption, trade openness, and carbon dioxide emissions in the BRICS countries (Brazil, Russia, India, China, and South Africa) by employing the Autoregressive Distributive Lag (ARDL) bounds testing method and Vector Error Correction Model (VECM) for the period 1971-2010. Their findings for the ARDL estimates reveal that there exists a long-run relationship between these variables. The VECM results reflect a bi-directional Granger causality between economic growth and renewable energy consumption, highlighting the positive impact of renewable energy on economic growth in the BRICS countries. This outcome supports the feedback hypothesis.

The neutrality hypothesis states that the absence of a causal relationship between economic growth and energy consumption makes them independent of one another (Yu \& Hwang, 1984; Yu \& Jin, 1992; Mehrara, 2007; Payne, 2009; Vlahinic-Dizdaravic \& Zikovic, 2010).

Most of the studies in the literature employ ARDL, Error Correction Model (ECM), VECM, Granger Causality, the Johansen Co-integration test, Dolado-Lutkepohl Causality, Pair-wise Granger Causality methods and techniques to explain the causal relationship between economic growth and energy consumption in Turkey (Akarca \& Long, 1980; Soytaş et al., 2001; Altınay \& Karagöl, 2005; Soytaş \& Sarı, 2006; Erdal et al., 2008; Erbaykal, 2008; Acaravc1, 2010; Öztürk \& Acaravc1, 2010; Kaplan et al., 2011; Acaravc1 \& Öztürk, 2012). 
The shortcoming in the literature is that there are only few studies that account for the presence of structural breaks, particularly in Turkey. For example, the relationship between economic growth and consumption of disaggregated energy sources under structural breaks is analyzed in Lee and Chang (2005) for Taiwan. Their results reveal that energy functions as an engine for the growth in Taiwan.

The relationship between natural gas consumption and economic growth with the consideration of structural breaks is investigated by Solarin and Shahbaz (2015) through the inclusion of Malaysian foreign direct investment (FDI), capital, and trade openness for the period of 1971-2012. The long-run relationship between the variables in the presence of structural breaks is analyzed by the structural break unit root and combined cointegration tests, and the ARDL bounds testing method. Their results reflect that natural gas consumption, FDI, capital formation, and trade openness affect the economic growth in Malaysia positively. The presence of the feedback hypothesis between natural gas consumption and economic growth, FDI, and economic growth, and natural gas consumption and FDI is supported with these results.

Saatçi and Dumrul (2013) analyze the effect of energy consumption including oil, electricity, coal, and renewable energy on economic growth in Turkey from 1960 to 2008. The results of the Kejriwal cointegration test indicate that in the presence of structural shifts the relationship between energy consumption and economic growth in Turkey is positive.

The aim of this study is to contribute to the insufficient body of literature on determinants of economic growth in Turkey in the presence of structural breaks. The sufficient analyses in the literature will provide more accurate results deemed necessary for policy implications for the sustainable economic growth in Turkey.

\section{Methodology}

\subsection{Economic Growth Model}

The present study examines the impact of changes in natural gas consumption and trade openness on the economic growth of Turkey, in addition to other determinants. This study considers the neoclassical growth model that takes the relationships between aggregate output, capital formation, and labor participation rate, expanded by natural gas consumption and trade openness determinants into account due to their important roles in the Turkish economy. There are empirical studies that employ the extended neoclassical growth model to analyze the relationships between economic growth and its determinants, like energy consumption and trade where authors employ real income per capita as a proxy for economic growth (Sarı \& Soytaş, 2007; Halıcıoğlu, 2011; Sadorsky, 2012; Shahbaz et al., 2013; Farhani et al., 2014; Doğan, 2015; Balitskiy et al., 2016). To our knowledge, there is no study in the literature that employs these determinants to analyze the Turkish economy. Iş1k (2010) employs a bivariate model where only natural gas consumption and economic growth are estimated. Doğan (2015) expands this model by adding capital formation and labor participation rate. Halıcıoglu (2011) analyzes the relationship between economic growth, 
capital formation, labor participation rate, energy consumption, and exports. Therefore, the relationships between the aggregate output of Turkey and its determinants can be expressed in the following form:

$$
\ln Y_{t}=\beta_{0}+\beta_{1} \ln N G_{t}+\beta_{2} \ln K_{t}+\beta_{3} \ln L_{t}+\beta_{4} \ln T O_{t}+\varepsilon_{t}
$$

where $Y_{t}$ is presented by the real GDP per capita. $N G_{t}$ is the consumption of natural gas per person, $K_{t}$ is the capital formation which is expressed in the gross capital formation as the share of the GDP, $L_{t}$ represents the labor participation rate in Turkey, and finally $T O_{t}$ is the trade openness expressed as sum of export and import as a share of the GDP at period $t$. $\varepsilon_{t}$ is the error term associated with each observation at period $t$. All determinants of output are expected to positively affect the economic growth of Turkey. In other words, all coefficients of regression (1) are expected to be positive.

\subsection{Cointegration Approach ${ }^{3}$}

\subsubsection{Structural Change Presence}

The period of this study 1977-2017 is characterized for Turkey by political and economic shocks. Therefore, structural shifts are important to analyze the determinants of economic growth. The Kejriwal and Perron (2010) method is employed in order to investigate the economic growth determinants in the case of multiple structural shifts. The Kejriwal and Perron approach is founded on the Bai and Perron (1998) framework, which is designed for estimations of only stationary variables in the presence of structural changes. Kejriwal and Perron (2010) extended their work in such a way that their methodology allows for both stationary as well as non-stationary variables to be used in estimations in the presence of multiple structural shifts, where serial correlation and heteroskedasticity are allowed. Limiting distributions of sup-Wald test that are derived with Bai and Perron (1998) method allow for the consideration of non-stationary variables in Kejriwal and Perron (2010).

This approach analyzes the following multiple linear regression where maximum $m$ breaks or $m+1$ regimes are allowed for:

$$
y_{t}=c_{i}+z_{f t}^{\prime} \delta_{f}+z_{b t}^{\prime} \delta_{b i}+x_{f t}^{\prime} \beta_{f}+x_{b t}^{\prime} \beta_{b i}+\varepsilon_{t}
$$

where $t=T_{j-1}+1, \ldots, T_{j}$ is the time period with $i=1, \ldots, m+1$ regimes. $y_{t}$ is an $I(1)$ dependent variable where $x_{f t}$ and $x_{b t}$ are the vectors of $I(0)$ covariates with the sizes $\left(p_{f} \times 1\right)$ and $\left(p_{b} \times 1\right)$; while $z_{f t}$ and $z_{b t}$ are the vectors of $I(1)$ independent variables with the sizes of $\left(q_{f} x l\right)$ and $\left(b_{q}\right.$ $x 1)$, respectively, where subscripts $f$ an $b$ represent "fixed" and "break" across the regimes term, and $\varepsilon_{t}$ is the error term of the model. The Kejriwal and Perron (2010) approach allows 
for the testing of the model for structural breaks for both cases where; only non-stationary variables and also, stationary and non-stationary variables are included in the model.

\subsubsection{Unit Root Tests}

The Kejriwal and Perron (2010) approach is based on the estimations of cointegrated regression models. Two alternative unit root tests were employed in this study in order to proceed with the cointegration tests. These are $\mathrm{Ng}$ and Perron (2001) and Carrion-i-Silvestre et al. (2009). The first test does not allow for the presence of structural shifts in series. The Generalized Least Squares (GLS) detrending procedure initially was suggested by Elliot, Rothenberg, and Stock (1996) to increase the efficiency of tests proposed by Perron and $\mathrm{Ng}$ (1996), and lately this procedure was employed in $\mathrm{Ng}$ and Perron (2001). The $\mathrm{Ng}$ and Perron (2001) test has maximum power against $I(0)$ alternatives. For the lag length selection, a minimized value of the modified Akaike information criterion (AIC) is used.

The second unit root in this study allows for multiple structural breaks in series in unknown locations under both the null and alternative hypotheses, which are nonstationarity and stationarity of series. This test is initially suggested by Kim and Perron (2009) and lately extended by Carrion-i-Silvestre et al. (2009). Alternative unit root tests, such as Zivot and Andrews (1992), Perron and Vogelsang (1992), Perron (1997), and Vogelsang and Perron (1998) allow for structural shifts depending on the assumption that they exist under the alternative hypothesis of stationarity.

Unit root tests are applied to series with respect to structural shifts existence. Thus, in order to examine the presence of structural breaks in time series the Perron and Yabu (2009) test is employed. The test is designed to seek the presence of structural shifts in univariate time series when their integration order is priori unknown. The Perron and Yabu test employs the Exp-W $W_{F S}$ test statistics, which is found with the quasi-Feasible Generalized Least Squares (FGLS) methodology. Andrews and Ploberger (1994) originally proposed the Exp function where the null hypothesis is no structural change in the deterministic components. Alternative models may be estimated by the test where structural breaks in the level are tested by model I. Model II is related to the slope of the trend and model III, which is employed in this study tests for the structural shift in both the level and the slope of the trend.

\subsubsection{Cointegration}

The cointegration characteristics of series are examined by the residual-based Engle and Granger (1987) cointegration test. Alternative unit root tests are performed on the residuals of the equation: The Augmented Dickey-Fuller (ADF) and the Phillips-Perron (PP) tests. The cointegration characteristics of series in the presence of structural shifts are investigated by the Maki (2012) test. The test is developed on the basis of two tests: one of them is the test for structural shifts analysis proposed by Bai and Perron (1998) and the second test is the unit root test when structural shifts are allowed (Kapetanios, 2005). The cointegration tests proposed by Maki (2012) allow for an unidentified number of breaks with 
the null hypothesis of no cointegration, against cointegration with an unknown number of shifts $i$, which have to be less than or the same as the maximum number of breaks $(i \leq k)$. The allowance of multiple structural breaks makes the Maki (2012) test superior compared to alternative tests due to the higher number of allowed structural shifts in cointegration relationships.

To test for cointegration in the presence of multiple structural shifts, Maki (2012) considers the following four regressions:

$$
\begin{aligned}
& y_{t}=\alpha+\sum_{i=1}^{k} \alpha_{i} D_{i, t}+\beta^{\prime} x_{t}+\varepsilon_{t} \\
& y_{t}=\alpha+\sum_{i=1}^{k} \alpha_{i} D_{i, t}+\beta^{\prime} x_{t}+\sum_{i=1}^{k} \beta^{\prime}{ }_{i} x_{t} D_{i, t}+\varepsilon_{t} \\
& y_{t}=\alpha+\sum_{i=1}^{k} \alpha_{i} D_{i, t}+\delta t+\beta^{\prime} x_{t}+\sum_{i=1}^{k} \beta^{\prime}{ }_{i} x_{t} D_{i, t}+\varepsilon_{t} \\
& y_{t}=\alpha+\sum_{i=1}^{k} \alpha_{i} D_{i, t}+\delta t+\sum_{i=1}^{k} \delta_{i} t D_{i, t}+\beta^{\prime} x_{t}+\sum_{i=1}^{k} \beta_{i}{ }_{i} x_{t} D_{i, t}+\varepsilon_{t}
\end{aligned}
$$

where $t=1,2 \ldots T$ is the time period and $k$ is the maximum number of breaks. $y_{t}$ is the dependent non-stationary variable which is the real GDP per capita, and $x_{t}$ is the vector of independent non-stationary variables which are: natural gas consumption per capita, capital formation as the share of GDP, the labor participation rate, and trade openness. $\alpha, \alpha_{i}, \delta, \delta_{i}$ are parameters, $\beta$ ' and $\beta^{\prime}{ }_{i}$ are vectors of parameters. $D_{i, t}$ determines a break location and takes a value of 1 if $1>T_{B i}$ and 0 otherwise, where $T_{B i}$ presents the time period of the break. When the number of breaks is one, this determines the test introduced by Gregory and Hansen (1996) that allows for only one structural shift. When the number of breaks is two, it coincides with the Hatemi-J (2008) cointegration test in which two structural shifts are allowed.

\section{Empirical Results}

The results of the Perron and Yabu (2009) test are presented in Table 1. Model III which tests for a structural break in both the level and the slope of the time trend is applied in this study. The null hypothesis of no structural shift was rejected in all variables except capital formation. As a result, structural shifts were found in the variables $Y, N G, L, T O$, and capital formation, $K$, which proved to be stable with no structural shifts. To examine the stationarity of the variables, the $\mathrm{Ng}$ and Perron (2001) unit root tests were applied in cases where structural shifts were not found. The Carrion-i-Silvestre et al. (2009) unit root tests were applied to time series where structural shifts were detected.

The Ng and Perron (2001) unit root tests were applied only to the capital formation variable. The results of the tests are presented in Table 2 and are all consistent with each other, providing the evidence of non-stationarity of the variable.

The integration order of other series with structural shifts was examined using the Carrion-i-Silvestre et al. (2009) unit root tests. Table 3 presents the $t$ statistics of the tests 
and detects the break locations $\widehat{T}_{i}$ in the last three columns. The integration order of variables was estimated with maximum three breaks, since the introduction of more breaks or their reduction did not significantly alter the results. Statistics of the unit root test were not able to reject the null hypothesis for any of the tested variables. Therefore, it can be concluded that both groups of variables that have structural shifts and are stable have unit roots.

\subsection{Structural Change Presence}

The Kejriwal and Perron (2010) approach, which is employed in this study requires the existence of cointegration relationships in models. Therefore, the cointegration relationships of equation (1) have to be examined first. Table 4 shows the results of the residual-based Engle and Granger (1987) cointegration test. The cointegration test is performed by employing the ADF and the PP unit root tests. The lag length selection was based on the AIC and on the Newey-West method for the ADF and the PP tests, respectively. Both tests rejected the null hypothesis of no cointegration at the $1 \%$ significance level. The results report that a cointegration relationship exists between the variables.

After detecting the cointegrating relationships between the variables the Kejriwal and Perron (2010) tests are conducted and reported in Table 5. The statistics of the Sup F $(l)$ for all values of $l$, except 5 are found significant. The UDmax column reports test statistics where the null hypothesis of absence of structural breaks is rejected. Results of the test indicate the presence of up to 4 structural breaks in the model. The last three columns indicate the number of breaks chosen by the sequential procedure (S), the Bayesian information criterion (BIC) and the modified Schwarz criterion (LWZ). The sequential procedure chose 3 breaks, the Bayesian information criterion selected 4 breaks, while the modified Schwarz criterion detected 1 break in the cointegrating relationship.

\subsection{Coefficients Estimates}

Estimation results of the regression coefficients (2) in the presence of structural shifts are reported in Table 6 . The dependent variable $y_{t}$ is expressed by the GDP per capita. The covariate $z_{t}$ is the vector of $I(1)$ explanatory variables which are: natural gas consumption per capita, capital formation as the share of GDP, labor participation rate, and trade openness. Coefficients are allowed to change across regimes and are estimated on the basis of sequential procedure where 3 breaks are detected. Results of the estimated coefficients are presented on the basis of the sub-regimes of 3 breaks. The test divides the period into $m+1$ sub-regimes where $m$ is the number of breaks. Therefore, there are four estimates for every variable according to periods between breaks. Estimates of break locations and their confidence levels at the $95 \%$ significance level are given in the last row of the table. Results of estimations provide evidence to conclude that investments and trade openness positively affect the economic growth of Turkey through estimated regimes. However, the impact of natural gas consumption and labor variables differ through regimes. Labor participation rate had a significant and highly negative effect on the economic growth during the 1977-1982 period, followed by an improving value in the 1982-1995 period. Its effect was estimated as positive after 1995 due to its rising value in the following period as of 2011. The highly 
negative impact of labor participation is detected in the 1977-1982 period when Turkey was negatively affected by the military coup, where the negative effect of employment may be explained by the inefficient use of labor at that period. After the elections of 1983 and with the appointment of the new prime minister of the Turkish Republic, Turgut Özal, the economic situation of Turkey, which may be seen from the rising values of the coefficients' of labor participation, improved.

Although, the coefficient of the natural gas consumption was found significant with a negative sign for the 1977-1982 period, indicating a negative relationship with economic growth; the results for the following periods gave positive values, but with declining effects. Measuring the effect of energy consumption on the economic growth of Turkey, Halıcioğlu (2011) found a positive and significant result. However, this study is consistent with some studies on the impact of particularly natural gas on economic growth of Turkey. Thus, Iş1k (2010), in the bivariate study, found; a significant and positive effect of natural gas on the economic growth of Turkey in the short term, and an opposite negative effect in the long term. Doğan (2015), after introducing capital and labor into the bivariate model estimated by Işı1k (2010), acquired a significant and negative impact of natural gas on the economic growth of Turkey for both short and long runs. However, studies for other countries have found positive impact of natural gas on economic growth, for example Apergis and Payne (2010), Shahbaz et al. (2013), and Öztürk and Al-Mulali (2015). Ignorance of the presence of structural shifts may create different results. The negative impact of natural gas consumption on the economic growth of Turkey may be due to its inefficient use and rising prices which increase the costs of production; thereby, leading to a decline in it. Turkey is dependent on imported natural gas that has prices, which are dependent not only on the price decisions of the producers but also on the changes in the exchange rates. Natural gas is used in both the residences and the industrial sectors where prices of output may not always rise at the same speed; hence, leading to a decline in production. Therefore, one important implication of this result for Turkey is to introduce policies directed to decrease the import dependency of natural gas supply. Trade openness was estimated at a relatively high value compared to the other determinants of the 1977-1983 period, indicating a strong impact on economic growth. This value remained positive through regimes; however, with a declining value, indicating the decreasing impact of trade openness through time.

The regression parameters estimated in the presence of structural shifts are compared to the coefficients estimated by the DOLS and FMOLS procedures, where breaks are not allowed, in Table 7. Results of the DOLS and FMOLS procedures are consistent with each other. However, signs and values of the DOLS and FMOLS coefficients are estimated for the whole period, while coefficients of the Kejriwal and Perron (2010) test provide different impacts of variables on the economic growth of Turkey for every sub regime. The DOLS and FMOLS coefficients report a significant and negative coefficient for natural gas, while the consideration of structural breaks illustrates that a negative impact existed only in the 1977-1982 period, with the following positive effects. Employment ratio is estimated with a positive sign in the DOLS and FMOLS regressions, while the consideration of structural shifts illustrates that the inefficient use of labor in the 1980s led to the decline in output, with the following change to a positive relationship between employment and economic growth. 
It is important to consider structural breaks if they exist, because the test results provide a better and different view on economic development through the shifts.

\subsection{Cointegration}

Table 8 demonstrates the results of the Maki (2012) cointegration test in the presence of multiple structural shifts. $M B k$ reports estimated the t-statistics of the Maki test where $k$ represents the maximum number of allowed breaks. When the number of breaks is two; the Maki test represents the case of the Hatemi-J (2008) test, which was designed for two structural breaks in the regression. The results indicate the existence of cointegration relationships in regression (1) in the presence of multiple unknown breaks. The null hypothesis of no cointegration was not rejected only in the case when the number of breaks equaled one, and the test statistics rejected the null hypothesis only at the $10 \%$ significance level in the case of two breaks. In all other cases, the test statistics reject the null hypothesis of no cointegration at the $1 \%$ significance level, demonstrating the presence of long run relationships in the model when more than 2 structural breaks are allowed.

\section{Conclusion}

This study examines the role of natural gas consumption, domestic investments, labor participation, and trade openness in the Turkish economic growth for the period throughout 1977 and 2017 in the presence of structural shifts. To test for the structural breaks' presence in series, the Perron and Yabu (2009) test was employed (Table 1). Two alternative unit root tests were employed to investigate the order of integration of time series. First, the $\mathrm{Ng}$ and Perron (2001) test (Table 2) was applied to variables, which were not exposed to structural shifts. Second, the Carrion-i-Silvestre et al. (2009) unit root test, Table 3, was applied to variables where the presence of structural breaks was detected in Table 1. The results of the unit root tests provided evidence to conclude that all of the variables in use are nonstationary.

The Kejriwal and Perron (2010) procedure was employed to test for structural breaks in growth equation (1). The results of the procedure, Table 5, report the existence of up to 5 structural shifts in the equation. The sequential procedure is chosen for breaks detection where 3 breaks are identified. The results of the coefficients' estimates in the presence of structural breaks, Table 6, are reported for the 4 sub-periods of 3 structural breaks. Natural gas consumption and employment ratio had a negative impact on the Turkish output during the 1977-1982 period, followed by the recovery to a positive impact in the following periods. Investments and trade openness are estimated with a positive sign through all regimes illustrating positive relationships. The regression parameters estimated by DOLS and FMOLS illustrated results that are averaged for the whole estimated period and do not provide detailed information on changes in tendencies due to structural shifts. The results of estimations' with allowed structural breaks revealed changes in the impacts of selected variables on economic growth through sub regimes. 
The presence of structural shifts in the regression does not allow us to employ an ordinary cointegration test without the consideration of structural shifts. Therefore, this study employed the cointegration test that enables the existence of structural breaks. The results of the Maki (2012) test provided evidence for the cointegration relationships between the determinants of economic growth in Turkey when two and more breaks are allowed in the regression.

The findings of this study indicate that the natural gas consumption affected output of Turkey negatively during the 1977-1982 period as of which it suggested a positive impact for the following periods, although not as high as it could be expected. The empirical results of this study offer policymakers a better insight into the economic growth determinants. $87.94 \%$ of energy consumption in Turkey depends on fossil fuels, such as petroleum, coal, and natural gas, which are relatively expensive and contain excessive percentage of carbon leading to a higher level of pollution. Turkey's excessive dependence on imported fossil fuels creates additional limitation to the economic growth of Turkey. Thus, the import dependence of Turkey on oil and natural gas was $93.3 \%$ and $98.6 \%$, respectively in 2012 . About $40 \%$ of the electricity production in Turkey is generated from natural gas resources. Rising natural gas consumption and oil prices escalated Turkey's payment for imported energy by almost $37 \%$ in 2017 compared to the previous year (Turkstat). Continuously increasing exchange rate escalates the cost of natural gas, which is becoming a cost shock to the Turkish economy, thereby negatively affecting aggregate production. Therefore, to maintain economic growth, Turkey must provide alternative and low-cost energy sources. About $30 \%$ of the electricity in Turkey is generated from domestic sources such as coal, which is the most air polluting energy source. Hence, domestic energy sources should not only be low-cost, but environmentally friendly as well for long-run development. One of the solutions which is the latest tendency in Turkey is to invest in renewable energy and increase its share. However, renewable energy has its disadvantages as well. It may not be continuously provided due to external weather conditions such as the wind or solar power. Renewable energy is far insufficient for the population of Turkey and her continuously growing and expanding industrial sector. The only visible solution for Turkey is nuclear power, which compensates for the shortcomings of other domestic and imported energy sources. First of all, nuclear energy is one of the least air polluting energy sources and it requires less area than any other renewable energy source. Nuclear energy power plants are environmentally friendly in case no accident happens. New generations of nuclear technologies significantly reduce an accident risk. The domestic nuclear energy production reduces the dependence of Turkey on foreign energy prices and the exchange rates. At the same time, compared to renewable energy, nuclear energy is continuously provided by power plants and does not depend on environmental conditions. The production of nuclear energy requires significant investments and time; however, it can significantly reduce the import dependence of Turkey and boost her economy.

Another important finding of this study indicates the significantly decreasing impact of trade openness on the output of Turkey through regimes. Table 6 illustrates how the impact of trade openness declined from a value of 18.826 in the $1977-1982$ period to 0.734 during the period 1995-2011. Results imply that the increase in trade openness led to a lower 
increase in output when compared to previous periods. However, trade openness may mean an increase in exports as well as an increase in imports, which reflects the Turkish case. The continuously increasing trade deficit makes the economy weaker. Increases in exchange rates and the prices of natural gas create cost shocks for the economy, thereby leading to: either a decline in economic growth or very slow growth. Therefore, policymakers have to pay more attention to policies that boost exports, in order to improve the positive impact of trade openness on economic growth and not to reverse it to a negative impact.

\section{References}

Abbasian, E. \& M. Nazari \& M. Nasrindost (2010), "Energy Consumption and Economic Growth in the Iranian Economy: Testing the Causality Relationship", Middle-East Journal of Scientific Research, 5(5), 374-381.

Acaravc1, A. (2010), "Structural Breaks, Electricity Consumption and Economic Growth: Evidence from Turkey", Journal for Economic Forecasting, 2, 140-154.

Acaravc1, A. \& I. Öztürk (2012), "Electricity Consumption and Economic Growth Nexus: A Multivariate Analysis for Turkey", Amfiteatru Economic, 14(31), 246-257.

Akarca, A.T. \& T.V. Long (1980), "On the Relationship between Energy and GNP: A Reexamination", The Journal of Energy and Development, 5(2), 326-331.

Altınay, G. \& E.T. Karagöl (2005), "Electricity Consumption and Economic Growth: Evidence from Turkey”, Energy Economics, 27, 849-856.

Andrews, D.W.K. \& W. Ploberger (1994), “Optimal tests when a nuisance parameter is present only under the alternative", Econometrica, 62, 1383-1414.

Apergis, N. \& J.E. Payne (2009), "Energy Consumption and Economic Growth: Evidence from the Commonwealth of Independent States", Energy Economics, 31, 641-647.

Apergis, N. \& J.E. Payne (2010), "Natural gas consumption and economic growth: A panel investigation of 67 countries", Applied Energy, 87, 2759-2763.

Aqeel, A. \& M.S. Butt (2001), "The Relationship between Energy Consumption and Economic Growth in Pakistan", Asia-Pacific Development Journal, 8(2), 101-110.

Arı, A. \& R. Cergibozan (2014), “The Recent History of Financial Crises in Turkey”, JETAS, 2(1), $31-46$.

Aydoğan, E.T. (2010), Capital Account Convertibility: The Turkish Case, Lap-Lambert Academic Publishing, ISBN-10: 3843367434.

Bai, J. \& P. Perron (1998), "Estimating and testing linear models with multiple structural changes", Econometrica, 66, 47-68.

Balitskiy, S. \& Y. Bilan \& W. Strielkowski \& D. Streimikiene (2016), "Energy efficiency and natural gas consumption in the context of economic development in the European Union", Renewable and Sustainable Energy Reviews, 55, 156-168.

Bartelmus, P. (1994), "Green Accounting for a National Strategy of Sustainable Development - The Case of Papua New Guinea", Ambio, 23(8), 509-514.

Belke, A. \& C. Dreger \& F. Haan (2010), "Energy Consumption and Economic Growth - New Insights into the Cointegration Relationship", Ruhr Graduate School in Economics, Ruhr Economic Papers, 190, 1-24. 
Binh, P.T. (2011), "Energy Consumption and Economic Growth in Vietnam: Threshold Cointegration and Causality Analysis", International Journal of Energy Economics and Policy, 1(1), 1-17.

Boratav, K. \& E. Yeldan (2006), “Turkey, 1980-2000: Financial Liberalization, Macroeconomic (In)stability, and Patterns of Distribution", in: L. Taylor (ed.) External Liberalization in Asia, Post-Socialist Europe, and Brazil, Oxford and New York, NY: Oxford University Press, 417-455.

Carrion-i-Silvestre, J.L. \& D. Kim \& P. Perron (2009), “GLS-based unit root tests with multiple structural breaks under both the null and the alternative hypotheses", Econometric Theory, 25, 1754-1792.

Cheng, B.S. \& T.W. Lai (1997), “An Investigation of Co-integration and Causality between Energy Consumption and Economic Activity in Taiwan”, Energy Economics, 19(4), 435-444.

Doğan, E. (2015), "Revisiting the relationship between natural gas consumption and economic growth in Turkey", Energy Sources, Part B: Economics, Planning, and Policy, 10(4), 361-370.

Elliott, G. \& T.J. Rothenberg \& J.H. Stock (1996), "Efficient tests for an autoregressive unit root", Econometrica, 64(4), 813-836.

Engle, R.F. \& C.W.J. Granger (1987), “Co-integration and error-correction: Representation, estimation and testing”, Econometrica, 55, 251-276.

Erbaykal, E. (2008), "Disaggregate Energy Consumption and Economic Growth: Evidence from Turkey", International Research Journal of Finance and Economics, 20, 1-8.

Erdal, G. \& H. Erdal \& K. Esengün (2008), "The Causality between Energy Consumption and Economic Growth in Turkey”, Energy Policy, 36(10), 3838-3842.

Ertuğrul, A. \& F. Selçuk (2001), “A Brief Account of the Turkish Economy, 1980-2000”, Russian and East European Finance and Trade, 37(6), 6-28.

Farhani, S. \& M. Shahbaz \& M. Arouri \& F. Teulon (2014), "The role of natural gas consumption and trade in Tunisia's output", Energy Policy, 66, 677-684.

Gregory, A.W. \& B.E. Hansen (1996), "Residual-based tests for cointegration in models with regime shifts", Journal of Econometrics, 70, 99-126.

Halıcıoğlu, F. (2011), “A dynamic econometric study of income, energy and exports in Turkey”, Energy, 36, 3348-3354.

Hatemi-J, A. (2008), "Tests for cointegration with two unknown regime shifts with an application to financial market integration", Empirical Economics, 35(3), 497-505.

Hatemi, A. \& M. Irandoust (2005), "Energy Consumption and Economic Growth in Sweden: A Leveraged Bootstrap Approach, 1965-2000", International Journal of Applied Econometrics and Quantitative Studies, 2(4), 87-98.

Hondroyiannis, G. \& S. Lolos \& E. Papapetrou (2002), "Energy Consumption and Economic Growth: Assessing the Evidence from Greece”, Energy Economics, 24(4), 319-336.

Hou, Q. (2009), “The Relationship between Energy Consumption Growths and Economic Growth in China", International Journal of Economics and Finance, 1(2), 232-237.

Hwang, D. \& B. Gum (1991), "The Causal Relationship between Energy and GNP: The Case of Taiwan", Journal of Energy and Development, 16(2), 219-226.

Işık, C. (2010), "Natural gas consumption and economic growth in Turkey: a bound test approach", Energy Systems, 1, 441-456. 
Kapetanios, G. (2005), "Unit-root testing against the alternative hypothesis of up to $\mathrm{m}$ structural breaks", Journal of Time Series Analysis, 26, 123-133.

Kaplan, M. \& I. Öztürk \& H. Kalyoncu (2011), "Energy Consumption and Economic Growth in Turkey: Cointegration and Causality Analysis", Romanian Journal for Economic Forecasting, 2011(2), 31-41.

Ketenci, N. (2016), "The bilateral trade flows of the EU in the presence of structural breaks", Empirical Economics, 51(4), 1369-1398.

Kim, D. \& P. Perron (2009), "Unit root test allowing for a break in the trend function under both the null and alternative hypothesis", Journal of Econometrics, 148, 1-13.

Kejriwal. M. \& P. Perron (2010), "Testing for multiple structural changes in cointegrated regression models", Journal of Business and Economic Statistics, 28(4), 503-522.

Kraft, J. \& A. Kraft (1978), “On the Relationship between Energy and GNP”, The Journal of Energy and Development, 3(2), 401-403.

Lee, C.C. \& C.P. Chang (2005), "Structural breaks, energy consumption, and economic growth revisited: Evidence from Taiwan", Energy Economics, 27(6), 857-872.

Maki, D. (2012), "Tests for cointegration allowing for an unknown number of breaks", Economic Modelling, 29(5), 2011-2015.

Masih, A.M.M. \& R. Masih (1997), "On the Temporal Causal Relationship between Energy Consumption, Real Income and Prices: Some New Evidence from Asian Energy Dependent NICs Based on A Multivariate Cointegration Error-Correction Approach”, Journal of Policy Modelling, 19, 417-440.

Mehrara, M. (2007), "Energy-GDP Relationship for Oil-Exporting Countries: Iran, Kuwait and Saudi Arabia", OPEC Review, 1-16, <http://ipac.kacst.edu.sa/eDoc/eBook/2387.pdf>, 22.02.2018.

Ng, S. \& P. Perron (2001), "Lag selection and the construction of unit root tests with good size and power", Econometrica, 69, 1519-1554.

Öztürk, I. \& A. Acaravc1 (2010), "Energy Consumption and $\mathrm{CO}_{2}$ Emissions Economic Growth in Turkey”, Renewable and Sustainable Energy Reviews, 14(9), 3220-3225.

Öztürk, I. \& U. Al-Mulali (2015), "Natural gas consumption and economic growth nexus: Panel data analysis for GCC countries", Renewable and Sustainable Energy Reviews, 51, 998-1003.

Perron, P. \& S. Ng (1996), "Useful modifications to some unit root tests with dependent errors and their local asymptotic properties", Review of Economic Studies, 63, 435-463.

Paul, S. \& R.N. Bhattacharya (2004), "Causality between Energy Consumption and Economic Growth in India: A Note on Conflict Results", Energy Economics, 26, 977-983.

Payne, J.E. (2009), “On the Dynamics of Energy Consumption and Output in the U.S.”, Applied Energy, 86(4), 575-577.

Perron, P. (1997), "Further evidence on breaking trend functions in macroeconomic variables", Journal of Econometrics, 80, 355-385.

Perron, P. \& T. Vogelsang (1992), "Nonstationarity and level shifts with an application to purchasing power parity", Journal of Business \& Economic Statistics, 10, 301-320.

Perron, P. \& T. Yabu (2009), "Testing for shifts in trend with an integrated or stationary noise component", Journal of Business and Economics Statistics, 27, 369-96.

Sadorsky, P. (2012), "Energy consumption, output and trade in South America", Energy Economics, 34(2), 476-488. 
Sari, R. \& U. Soytaş (2007), "The growth of income and energy consumption in six developing countries", Energy Policy, 35, 889-898.

Saatçi, M. \& Y. Dumrul (2013), "The Relationship between Energy Consumption and Economic Growth: Evidence from A Structural Break Analysis for Turkey", International Journal of Energy Economics and Policy, 3(1), 20-29.

Sebri, M. \& O. Ben-Salha (2014), "On the causal dynamics between economic growth, renewable energy consumption, $\mathrm{CO}_{2}$ emissions and trade openness: Fresh evidence from BRICS countries", Renewable and Sustainable Energy Reviews, 39, 14-23.

Shahbaz, M. \& H.H. Lean \& A. Farooq (2013), "Natural gas consumption and economic growth in Pakistan", Renewable and Sustainable Energy Review, 18, 87-94.

Solarin, S.A. \& M. Shahbaz (2015), "Natural gas consumption and economic growth: The role of foreign direct investment, capital formation and trade openness in Malaysia", Renewable and Sustainable Energy Reviews, 42, 835-845.

Souhila, C. \& B. Kourbali (2012), "Energy Consumption and Economic Growth in Algeria: Cointegration and Causality Analysis", International Journal of Energy Economics and Policy, 2(4), 238-249.

Soytaş, U. \& R. Sarı (2006), “Energy Consumption and Income in G-7 Countries”, Journal of Policy Modeling, 28(7), 739-750.

Soytaş, U. \& R. Sarı \& O. Özdemir (2001), "Energy Consumption and GDP Relation in Turkey: A Cointegration and Vector Error Correction Analysis. Economies and Business in Transition: Facilitating Competitiveness and Change", The Global Environment Proceedings, 838-844.

Vogelsang, T.J. \& P. Perron (1998), “Additional Tests for a Unit Root Allowing for a Break in the Trend Function at an Unknown Time", International Economic Review, 39, 1073-1100.

Thoma, M. (2004), "Electrical Energy Usage over the Business Cycle”, Energy Economics, 26(3), 463-485.

Vlahinic-Dizdarevic, N. \& S. Zikovic (2010), "The Role of Energy in Economic Growth: The Case of Croatia”, Zb. rad. Ekon. fak. Rij, 28(1), 35-60.

Yong-Xiu, H. \& L. De-Zhi \& L. Yan (2007), "Research on the Cointegration Relationship of Energy Consumption and Economy Growth in Beijing", WSEAS Transactions on Environment and Development, 3(9), 165-170.

Yu, E.S.H. \& J.Y. Choi (1985), "The Causal Relationship between Energy and GNP: An International Comparison", The Journal of Energy and Development, 10(2), 249-272.

Yu, E.S.H. \& B-K. Hwang (1984), “The Relationship between Energy and GNP: Further Results”, Energy Economics, 6(3), 186-190.

Yu, E.S.H. \& J.C. Jin (1992), "Cointegration Tests of Energy Consumption, Income and Employment”, Resources and Energy, 14(3), 259-266.

Zamani, M. (2007), "Energy Consumption and Economic Activities in Iran”, Energy Economics, 29(6), 1135-1140.

Zivot, E. \& D. Andrews (1992), "Further evidence of great crash, the oil price shock and unit root hypothesis", Journal of Business and Economic Statistics, 10(3), 251-270.

Zhang, X-P. \& X-M. Cheng (2009), "Energy Consumption, Carbon Emissions and Economic Growth in China", Ecological Economics, 68(10), 2706-2712. 
Table: 1

The Perron - Yabu (2009) Test

\begin{tabular}{|c|c|c|}
\hline Variables & EXP-W & $\hat{T}_{1}$ \\
\hline$Y$ & $3.44^{*}$ & 2000 \\
\hline$N G$ & $42.43^{* *}$ & 1988 \\
\hline$K$ & 0.63 & 2003 \\
\hline$L$ & $84.23^{* *}$ & 2002 \\
\hline$T O$ & $167.84^{* *}$ & 2 \\
\hline
\end{tabular}

Notes: * and** denote the rejection of the null hypothesis at the $5 \%$ and $1 \%$ significance levels. Trimmer parameter $\varepsilon=0.15$ is used. The critical values are taken from Perron and Yabu (2009), Table 2c.

Table: 2

The Ng and Perron (2001) Unit Root Test

\begin{tabular}{|c|c|c|c|c|}
\hline Country & $\mathrm{MZ}_{\alpha}{ }^{\mathrm{GLS}}$ & $\mathrm{MZ}^{\mathrm{GLS}}$ & $\mathrm{MSB}^{\mathrm{GLS}}$ & MP $_{\mathrm{T}}{ }^{\mathrm{GLS}}$ \\
\hline$K$ & $-19.98^{*}$ & $-3.16^{*}$ & $0.16^{*}$ & $1.22^{*}$ \\
\hline
\end{tabular}

Notes: $M Z_{\alpha}^{G L S}$ is the modified Phillip-Perron test $M Z_{\alpha} ; M Z_{t}^{G L S}$ is the modified Phillip-Perron $M Z_{t}$ test; $M S B^{G L S}$ is the modified Sargan-Bhargava test; $M P_{T}^{G L S}$ is the modified point optimal test, for details see Ng and Perron (2001). The order of lag to compute the test has been chosen using the modified AIC (MAIC) suggested by Ng and Perron (2001). The critical values for the above tests have been taken from Ng and Perron (2001).

Table: 3

The Carrion-i-Silvestre et al. (2009) Unit Root Test

\begin{tabular}{|c|c|c|c|c|c|c|c|}
\hline Country & $\mathrm{MZ}_{\alpha}^{\mathrm{GLS}}$ & $\mathrm{MZ}_{\mathrm{i}}^{\mathrm{GLS}}$ & $\mathrm{MSB}^{\mathrm{GLS}}$ & $\mathrm{MP}_{\mathrm{T}}{ }^{\mathrm{GLS}}$ & $\hat{T}_{1}$ & $\hat{T}_{2}$ & $\hat{T}_{3}$ \\
\hline $\mathrm{Y}$ & -19.42 & -3.11 & 0.16 & 14.87 & 1981 & 1999 & 2004 \\
\hline $\mathrm{NG}$ & -14.97 & -2.73 & 0.18 & 18.54 & 1981 & 1986 & 2005 \\
\hline $\mathrm{L}$ & -17.69 & -2.97 & 0.17 & 12.28 & 1981 & 1985 & 1990 \\
\hline TO & -15.69 & -2.78 & 0.18 & 13.92 & 1981 & 1985 & 1990 \\
\hline
\end{tabular}

Notes: The critical values were obtained by simulations using 1,000 steps to approximate the Wiener process and 10,000 replications. The test is run for model 3, where the structural break affects both the level and the slope of the time trend. Note that for the MSB and MPT tests the null hypothesis is rejected in favor of stationarity when the estimated value is smaller than the critical value.

Table: 4

\section{The Engle-Granger (1987) Cointegration Test}

\begin{tabular}{|c|c|}
\hline ADF & PP \\
\hline$-3.98 *(0)$ & $-3.99 *(2)$ \\
\hline
\end{tabular}

Notes: * denotes statistical significance at $1 \%$ level. Lags of the ADF regressions were selected using AIC and are presented in brackets of the second column. Truncation lags for PP regressions are selected using the Newey-West method and are presented in brackets in the second column. 
Table: 5

The Kejriwal and Perron (2010) Test

\begin{tabular}{|c|c|c|c|c|c|c|c|c|}
\hline Sup F(1) & Sup F(2) & Sup F(3) & Sup F(4) & Sup F(5) & UDmax & S & BIC & LWZ \\
\hline $24.19^{*}$ & $12.52^{*}$ & $9.42 *$ & $7.24^{*}$ & 3.08 & $24.19^{*}$ & 3 & 4 & 1 \\
\hline
\end{tabular}

Notes: * denotes statistical significance at 5\% level. The 5\% critical values for the supF(l) test in the case of nonstationary variables are 8.58, 7.22, 5.96, 4.99 and 3.91 for $l=1,2,3,4,5$ respectively. Critical value for UDmax test is 10.26 see Kejriwal and Perron (2010), category (a) model 2. BIC - Bayesian Information Criteria, LWZ - the modified version of BIC proposed by Liu et al. (1997), and sequential procedures are used for the selection of breaks number.

Table: 6

The Kejriwal and Perron (2010) Test - Estimated Coefficients

\begin{tabular}{|c|c|c|c|c|}
\hline Procedure (S-3 Breaks) & sub-regime 1 & sub-regime 2 & sub-regime 3 & sub-regime 4 \\
\hline$\widehat{N G}$ & $-0.737^{*}(0.256)$ & $0.011(0.007)$ & $0.262^{*}(0.015)$ & $0.072(0.178)$ \\
\hline$\widehat{K}$ & $-0.367(0.264)$ & $0.076(0.048)$ & $0.379^{*}(0.033)$ & $0.979^{* *}(0.480)$ \\
\hline$\widehat{L}$ & $-10.014^{*}(4.053)$ & $-0.952^{*}(0.181)$ & $0.848^{*}(0.142)$ & $1.676^{*}(0.637)$ \\
\hline$\widehat{T O}$ & $18.826^{*}(6.351)$ & $4.326^{*}(0.277)$ & $0.734^{*}(0.233)$ & $-0.431(0.734)$ \\
\hline Break dates $\widehat{T}_{i}$ & \multicolumn{3}{|c|}{$1982(1981-1983), 1995(1994-1996), 2011(2010-2012)$} \\
\hline
\end{tabular}

Notes: Numbers in parentheses under coefficients estimates are standard errors. The parentheses under the break points are $95 \%$ confidence intervals for the break dates.

**, * Denote statistical significance at the 1 and $5 \%$ level respectively.

Table: 7

Estimated Coefficients

\begin{tabular}{|c|c|c|c|c|c|}
\hline Model & $\boldsymbol{\beta}_{0}$ & $\widehat{N G}$ & $\widehat{K}$ & $\widehat{L}$ & $\widehat{T O}$ \\
\hline DOLS & $\begin{array}{c}-80.84^{* *} \\
(9.07)\end{array}$ & $\begin{array}{c}-0.08^{* *} \\
(0.02)\end{array}$ & $\begin{array}{c}0.57^{* *} \\
(0.07)\end{array}$ & $\begin{array}{c}0.32^{* *} \\
(0.16)\end{array}$ & $\begin{array}{c}30.48^{* *} \\
(3.09)\end{array}$ \\
\hline FMOLS & $-77.04^{* *}(2.51)$ & $-0.06^{* *}(0.01)$ & $0.45^{* *}(0.04)$ & $0.58^{* *}(0.11)$ & $28.85^{* *}(0.87)$ \\
\hline
\end{tabular}

Notes: * denotes statistical significance at $5 \%$ level. ** denotes statistical significance at $1 \%$ level.

Estimated coefficients are from equation (1), where $\beta_{0}$ is a constant. AIC criteria is used to select the number of leads and lags in DOLS.

\section{Table: 8}

The Maki (2012) Cointegration Test

\begin{tabular}{|c|c|c|c|c|}
\hline MB1 & MB2 & MB3 & MB4 & MB5 \\
\hline-5.42 & $-7.39^{\prime}$ & $-9.56^{*}$ & $-9.59^{*}$ & $-9.59^{*}$ \\
\hline
\end{tabular}

Notes: Critical values are taken from Maki (2012) - Table 1.

* denotes statistical significance at the 1\% level, 'denotes statistical significance at the 10\% level. 